tion, and at present preparations are being made for the construction of a shed which will take in the largest size of dirigible. The Admiralty has in prospect one great rigid dirigible, the War Office has three, and besides those we have our balloons for war purposes. At the present time we have certain aëroplanes, and the prospect of two new aëroplanes which are to be presented for experimental purposes, and may hereafter be acquired. That is the actual position of things.

\section{IMPROVEMENTS IN PRODUCTION AND APPLICATION OF GUNCOTTON AND NITROGLYCERINE.'}

II.

I $N$ the year 1846 Schönbein discovered guncotton. In the year 1886, that is, forty years later, the French chemist Vieille invented his smokeless powder for military purposes. This explosive, which was primarily designed for use in the small calibre Lebel rifle, consisted essentially of guncotton, and the secret of its success lay in the fact that Vieille so altered its physical state that its rate of combustion, when confined, was under complete control. This condition was arrived at by treating the fibrous guncotton with suitable solvents which entirely destroyed the fibre and converted it into a colloidal, horny substance quite devoid of all porosity. The gelatinised guncotton resulting from this treatment burnt, when ignited, from the surface inwards, and by varying the surface area any required rate of combustion could be obtained. The use of smokeless powders manufactured in this way was very soon extended to all natures of ordnance.

The next step in the development of smokeless powders was the combination of nitroglycerine with nitrocellulose. The first powder of this type was the "ballistite" of Alfred Nobel, patented by him in the year. I888. The original ballistite was composed of equal parts of nitroglycerine and of soluble nitrocellulose, a variety of guncotton soluble in nitroglycerine, and no solvent was therefore required in its preparation, although a certain proportion of camphor was used to promote the solution of the nitrocellulose. Another form of nitroglycerine-nitrocellulose explosive is the British service powder, cordite, which originally consisted of nitroglycerine, $5^{8}$ parts, guncotton, insoluble in nitroglycerine, 37 parts, and mineral jelly, a product of the distillation of crude petroleum, 5 parts. To effect the gelatinisation of the guncotton, the solvent acetone, obtained indirectly from the destructive distillation of wood, is employed. The result of subjecting nitrocellulose in suitable machines to the action of nitroglycerine or of solvents, of which there are several suitable ones besides acetone, is to destroy its fibre and convert it into a gelatinous mass, in which condition $i$ can be formed into any desired shape. Where solvents are used to produce this result they remain in the mas during subsequent operations, and are finally driven of by means of heat. The resulting products, somewhat incorrectly termed "powders," which are manufactured in a variety of forms, such as grains and fiakes of differen shapes, ribbons or strips, solid cords, tubes, \&c., vary in consistence with the quantity of nitroglycerine they contain. The more nitroglycerine present the softer the powder, pure nitrocellulose powders being hard to brittleness.

For practical purposes modern smokeless powders are of two types:-

(I) Those consisting entirely of nitrocellulose, and termed " nitrocellulose powders."

(2) Those consisting of a mixture of nitrocellulose and nitroglycerine, known as " nitroglycerine powders."

Opinions differ somewhat as to the relative merits of these two types; in this country the latter type is preferred. Their characteristic features are, briefly, as follows :-

A nitroglycerine powder is more powerful than a nitrocellulose powder, and the more nitroglycerine present the more powerful the explosive. Therefore, for equal ballistics, a smaller charge of the former than of the latter is required, and, consequently, the chamber capacity and 1 Discourse delivered at the Royal Institution on Friday, January 29, by Sir Frederic L. Nathan, R.A. Continued from p. I47. NO. 20\%5, VOL. $8 \mathrm{I}]$ the size and weight of the breech mechanism are reduced; on the other hand, the higher the proportion of nitroglycerine the higher is the temperature of combustion and the greater the erosive effects on the surface of the bore of the gun.

The presence of nitroglycerine in an explosive allows of the more easy and rapid elimination of the solvent used in manufacture and of moisture, a small quantity of which is always present in nitroglycerine and guncotton. The sooner this is attained the better, because the ionger the time that the powder is being heated in order to dry it, the more likely is its chemical stability to be affected. Moreover, it is a well-established fact that with nitrocellulose powders it is impossible to remove the volatile matter with anything like the same completeness as can be done in the case of nitroglycerine powders. The consequence is that the slow evaporation from nitrocellulose powders of the residual volatile matter which takes place in store tends to produce changes in their physical character and renders them in course of time liable to alter in ballistic properties, and even to develop dangerous pressures in the gun.

Nitroglycerine powders are cheaper than nitrocellulose powders, weight for weight, and even more so for equal ballistic effects.

The original cordite, the manufacture of which commenced in 1890 , contained a high proportion of nitroglycerine, $5^{8}$ per cent., and the erosion produced, especially in large guns, was considerable. This led to experiments being carried out at Waltham Abbey with the view of the production of a less erosive explosive, and the final result was the introduction into the service, in I901, of a modified cordite known as "cordite M.D.," in which the percentage of nitroglycerine is reduced to 30 per cent. so that the composition becomes:-nitroglycerine, 30 per cent.; guncotton, 65 per cent.; and mineral jelly, 5 per cent.

The constants of explosion of cordite and cordite M.D., determined at the Royal Gunpowder Factory some little time ago, are as follows:-

\begin{tabular}{|c|c|c|c|c|}
\hline Explosive & $\begin{array}{l}\text { Density of } \\
\text { Loading }\end{array}$ & $\begin{array}{c}\text { Heat of Explo- } \\
\text { ion at Constant } \\
\text { Volume, Water } \\
\text { Gaseous }\end{array}$ & $\begin{array}{l}\text { Total Gases. } \\
\text { Water } \\
\text { Gaseous } \\
\text { at } 0^{\circ} \mathrm{C} . \\
760 \mathrm{~mm} .\end{array}$ & $\begin{array}{l}\text { Temperature } \\
\text { of Explosion }\end{array}$ \\
\hline Cordite $\quad \ldots$ & 0.2 & $\begin{array}{l}\text { Calories per } \\
\text { gram } \\
\text { I I } 56\end{array}$ & $\begin{array}{l}\text { c.c. per gram. } \\
87 \mathrm{I}\end{array}$ & $\begin{array}{l}{ }^{\circ} \mathrm{C} . \\
{ }_{266} 6{ }_{3}\end{array}$ \\
\hline Cordite M.D. & 0.2 & 965 & 920 & 2374 \\
\hline
\end{tabular}

An inspection of these figures shows that the alteration in proportions of the explosive ingredients results in a decrease in the heat of explosion of about $16 \frac{1}{2}$ per cent., and an increase in the volume of gases of about $5 \frac{1}{2}$ per cent., whilst there is a decrease of $289^{\circ} \mathrm{C}$. in the temperature of explosion.

As would therefore be expected, the erosion produced by cordite M.D. is very much less than that produced by the original cordite for the same ballistics, and is certainly not greater, if as great, as that produced by the best forms of nitrocellulose explosives.

Although of minor importance to smokelessness, flamelessness is a desirable quality for propulsive explosives to possess. In this respect cordite M.D. is superior to cordite in the case of rifles and machine guns; unfortunately, a suitable ingredient has not yet been discovered which will render smokeless powders flameless in large guns.

A third ingredient in both natures of cordite, viz. mineral jelly, although present in a comparatively small proportion, is a very important constituent.

Cordite in the advanced experimental stage consisted of nitroglycerine and guncotton alone, and as their combustion produced no solid residue of any kind, the surface of the bore of the magazine rifle in which the early experiments took place was not fouled in any way. The result was that the cupro-nickel coated bullets, propelled in succession at high velocity through a clean barrel, deposited some of the cupro-nickel in the bore. In order to prevent this a number of substances were incorporated with the nitroglycerine and guncotton, with the object 
of producing a deposit in the bore, which it was hoped would get rid of the difficulty of metallic fouling. Of all these various substances the one which appeared to answer the purpose most satisfactorily was refined vaseline, and this material became the third ingredient of cordite as eventually introduced into the British service. When the manufacture was commenced on a large scale, vaseline, which is the proprietary name of one of the refined products of the distillation of petroleum, was replaced by mineral jelly, the same material, but in a cruder form.

The original object with which mineral jelly was introduced was of no importance when cordite was substituted for the black and brown powders used in large guns, but in order to have but one nature of smokeless powder in the service mineral jelly was added to all cordite, whether for use in small arms or artillery. Subsequent experience has demonstrated how very fortunate was the selection of this material for rifle cordite and the extension of its use to all sizes of cordite.

Mineral jelly is one of the best ingredients it is possible to have in smokeless powders from the point of view of their chemical stability. This important fact, not recog nised originally, was brought out in the following way. In order to facilitate the explosion of cordite in blank ammunition for the rifle it was cut into very thin flakes, and the non-explosive mineral jelly was omitted from its composition. After a comparatively short storage in a hot climate the stability of the smokeless blank, as it was called, was found to have suffered seriously, whereas the stability of normal cordite containing mineral jelly was not appreciably affected. These facts led to a thorough investigation at Waltham Abbey of the action of mineral jelly in preserving the stability of cordite, and it was discovered that mineral jelly contained constituents which had the valuable property of combining with the decomposition products (the result of prolonged storage of cordite at high temperatures) to form stable bodies, thus removing these decomposition products, which undoubtedly exert a deteriorating influence on the cordite from their sphere of action.

When Abel was engaged on his researches in connection with the production and properties of guncotton, it was obvious to him that some test of a chemical nature was required in order to ascertain whether or not the finished guncotton had been thoroughly purified in manufacture. It will be remembered that accidents occurred in the early days of its production because this purification had not been carried sufficiently far. The test which he devised was based on the principle that if guncotton be subjected to an elevated temperature, traces of oxides of nitrogen will be given off, and will reveal their presence by acting on a suitable reagent.

The test is carried out by heating guncotton in a testtube placed in a water bath, and suspending over it a strip of moistened filter paper impregnated with potassium iodide and starch. If the purification of the guncotton has not been sufficient, the discoloration of the test paper takes place early; as the result of experience Abel fixed a time before which no reaction should take place. This test, known as the Abel heat test, is a test for the purity of guncotton and of nitroglycerine, and of freshly made explosives containing either one or both of these ingredients. For this purpose no test has yet been devised which equals it. But it was never intended to be, and is not, a quantitative test, and is therefore only a rough guide, though a very useful one, as to the stability of an explosive which has been in store for more or less prolonged periods, or under more or less adverse conditions.

Smokeless powders of the types dealt with are all subject to deterioration, and there is very little doubt that this deterioration is for any given explosive a function of the temperature of storage. The higher the temperature the more rapid the deterioration.

The necessity, therefore, of some quantitative test which would enable a judgment to be formed as to the extent of deterioration suffered by any given sample of cordite is obviously of great importance, because such a test would afford the means of determining how much longer it would be safe to store any given batch of cartridges or lot of cordite at any given temperature. Any such test

$$
\text { NO. } 2075 \text {, VOL. 8I] }
$$

must be a heating test, and it must be possible to correlate the temperature and duration of the test with any given temperature and duration of storage. The rate of deterioration as a function of the temperature was determined by Dr. Will for guncotton, and later by Dr. Robertson at Waltham Abbey for nitroglycerine. From these and other experiments carried out at Waltham Abbey, a factor of increase in rate of deterioration of cordite with increase of temperature was deduced. This factor having been determined, what is known as the "silvered vessel test" was worked out at the Royal Gunpowder Factory. In this test, of which the details will be described presently, cordite is heated in a specially designed vessel at $80^{\circ} \mathrm{C}$., a temperature not too far removed from those to be met with when cordite is stored under the worst service conditions, and the number of hours' heating at this temperature any given sample will stand before it shows signs of active decomposition are ascertained. Then, by means of an equation, containing the factor connecting rate of increase of deterioration with rise in temperature, a calculation can be made converting the hours of heating at $80^{\circ}$ C. the sample withstood to years and fractions of a year it would stand at any given temperature of storage, and therefore a knowledge is obtained of how much longer it would be safe to store this cordite at any given temperature.

This test was applied to a considerable number of samples of known age and thermal history. From these data, and knowing the number of hours at $80^{\circ} \mathrm{C}$. that newly made cordite of good stability will stand before showing signs of decomposition, the number of hours that the different samples should stand the test were calculated. When the samples were actually tested, the number of hours' heating at $80^{\circ} \mathrm{C}$. they withstood were in close agreement with the number of hours it was calculated they should stand.

The form of vessel in which the heating is carried out is the well-known vacuum vessel of Sir James Dewar. A glass bulb silvered externally is enclosed in an outer bulb silvered internally. The space between the two is highly evacuated for the purpose of limiting the dissipation of any heat evolved by exothermic changes on the one hand, and on the other for the purpose of minimising the effect of accidental slight changes in temperature of environment.

In the centre of the inner bulb is situated the bulb of a thermometer, the stem of which passes through a cork in the neck of the vessel. A side tube is attached for the purpose of making observations on the colour of the gases evolved. For heating the vessel a bath is provided with cylinders closed at the bottom, and wide enough to admit the vessel to such a depth as the side tube will permit. The bath is surrounded by insulating materials. The vessels are packed in the cylinders with wool yarn, and the tops of the cylinders are closed with felt discs to exclude draughts.

The bath is fitted with a gas regulator or other means for securing that the temperature of the explosive is kept constant.

The cordite is coarsely ground, and 50 grams are used.

Readings of the thermometer are taken at intervals, and the time is noted when a rise of $2^{\circ} \mathrm{C}$. in the temperature of the explosive above the temperature of $80^{\circ} \mathrm{C}$. occurs. At the same time, visual observations are made as to the colour of the column of gas in the side tube, since it is found that, previous to the rise in temperature occurring, orange-coloured fumes of nitric peroxide are evolved. 'When the temperature exceeds $82^{\circ} \mathrm{C}$. the test is complete, and the flask is withdrawn. The number of hours which have elapsed since the start of the test is the measure of the stability of the cordite.

Until about sixty years ago, the only explosive known for all purposes was gunpowder. With the discovery of guncotton and nitroglycerine, gunpowder was gradually replaced by them for blasting purposes. In their early days the two explosives were used singly, guncotton as guncotton, nitroglycerine-first of all alone-and then as dynamite. Later on the two were combined as blasting gelatine and explosives of a similar nature, but it was quite forty years after their discovery before either became of practical use for propulsive purposes. 
The invention of "Poudre B" by Vieille marked the commencement of a new era in connection with the science of artillery, and it was not long before smokeless powders made from the violent guncotton, or of guncotton combined with the still more violent nitroglycerine, entirely superseded the centuries-old gunpowder. Modern explosives are characterised by very greatly increased power, giving enormously greater range to projectiles fired from both rifles and artillery, thus altering entirely the conditions of both land and naval warfare.

It is at present not easy to forecast in what direction further improvements in propellants will take place. It is also difficult to conceive what the explosive of the future will be which will produce a change as revolutionary as that which took place when smokeless powders superseded the old-fashioned black powders. For some time to come, probably, the manufacturer of explosives will have to content himself with endeavours to improve them as far as he can, both from a ballistic and from a stability point of view, with the ingredients now at his disposal.

\section{UNIVERSITY AND EDUCATIONAL}

\section{INTELLIGENCE}

Dr. A. Robinson, professor of anatomy in the University of Birmingham, has been appointed to the chair of anatomy in Edinburgh University in succession to the late Prof. D. J. Cunningham, F.R.S.

IT is stated by the Frankfurt Gazette that the National Assembly of Iceland has decided to establish a university at Reikjavik, the capital of the island. The new university is to have four faculties, with sixteen professors and lecturers.

Mr. EDWIN TATE has presented new library buildings to Battersea Polytechnic. The total book accommodation is 20,000 volumes. The cost of the buildings, including fittings, is estimated at about $6000 l$, and the whole is being defrayed by Mr. Tate.

A CORRESPONDENT informs us that the appointments to the chairs of chemistry in the Technical High School at Munich have just been officially announced. The names of the various professors are:-organic chemistry, Prof. Semmler; inorganic chemistry, Prof. A. Stock; physical chemistry, Prof. R. Abegg. Each professor has an institute of his own, and Prof. Abegg retains, at the same time, his position as extraordinary professor in the University of Breslau. The Technical High School, which is being built at a cost of something like five million marks, is making good progress, and is to be opened officially in October, I9Io.

THE commencement address last June at the South Dakota School of Mines, Rapid City, South Dakota, was delivered by the president of the Colorado School of Mines, Mr. Victor C. Alderson, who took for his subject "Artist or Artisan-Which?" "The artisan," he said, "understands machinery; the artist-engineer is a master of the kinematics of machines. The artisan works with his hands and lets his mind rest; the artist-engineer uses his brains to relieve his hands. The artisan becomes a skilled workman and no more; the artist-engineer sees beyond the mere machinery to the economic management of his plant, to the percentage saving possible, to the market for his product, to the efficient service of his employees, to the general success of the entire plant. To do all this he must have an ideal." Every young engineer, he proceeded to say later, should decide early in life whether he will become merely an artisan-engineer or an artist-engineer. Mr. Alderson then gave some inspiring advice to young engineers as to the physical. personal, intellectual, and moral characteristics they should strive to develop. Incidentally, he said the chance for the untrained or uneducated man to make a success in this age is practically nil. Taking "Who's Who" as a standard of national prominence in America, it is found, said Mr. Alderson, that it takes approximately Io,ooo grammar-school pupils to produce one man worthy to be enrolled in "Who's Who." Of high-school students 250 suffice, while of fifty college graduates one will, on the average, rise to sufficient prominence to be enrolled in this book.

$$
\text { NO. } 2075 \text {, VOL. 8I] }
$$

TIIE proceedings in connection with the celebration of the 5ooth anniversary of the founding of the University of Leipzig began on July 28 , when a reception was given by the University to the representatives of German and foreign universities and learned societies invited to participate in the proceedings. On the following day a festival service in the University Church was attended by the King of Saxony. A commemorative meeting in the new theatre followed the service, and the King delivered an address and presented two medallions to the University to be worn in future by the rector of the University on his chain of office. The medallions bear images of the King of Saxony and of the founder of the University. The Saxon Minister of Education in an address afterwards outlined the history of the University. On July 30 further commemoration speeches were delivered. Prof. Wundt was the principal speaker, and during the course of his speech remarked, although the German people seem to be in the current of an intellectual movement in which the demand for higher education is hardly less strong than was the revival of learning in the Middle Ages, ho said, in the words of Leibnitz, "It is the past which contains the future." Prof. Mahaffy spoke on behalf of the British delegates. The following honorary degrees were conferred among others:- Doctor of Medicine, Prof. E. B. Wilson, of Columbia University; Doctors of Philosophy, Sir Archibald Geikie, K.C.B., P.R.S., Prof. J. Loeb, of California University. Prof. J. Ward, of Cambridge University, and Mr. F. I. Griffith, reader in Egyptology. Oxford University.

\section{CONTENTS.}

PAGE

What the Electrician Wants. By Maurice Solomon I5I The Thermodynamics of the Earth . . . . . . I52 Archæology at Avebury. By R. H. C. . . . . . . 154 Venoms and Anti-venoms . . . . . . . I54

The Scottish Lake Survey. By H. R. M. . . . . . I55 The Old and the New Mechanics . . . . . . 156 Our Book Shelf :-

Bailey: "The State and the Farmer". ...... I57

"The Problem of the Feeble-minded" . . . . . . 158

Watt: "The Economy and Training of Memory", . I58

\section{Letters to the Editor:-}

Rate of Helium Production from the Complete Series of Uranium Products.-Hon. R. J. Strutt, F.R.S.

A Kinematic Illusion. -W. B. Croft

Natural Selection and Plant Evolution.-James B. Johnston

Musical Sands,-Cecil Carus.Wilson

A Question of Percentages.-J. T. Cunningham.
The Upper Cretaceous Iguanodont Dinosaurs. (Illustrated.) By H. F. O.

Nature Studies in New Zealand and at Home. (Illustrated.)

Researches at the National Physical Laboratory.

By C. H. L. . . . . . . . . . . 163 John Reid, 1809-1849. By Dr. D. Fraser Harris : 163

\section{otes}

Our Astronomical Column :-

Movements in the Sun's Upper Atmosphere . . . . I70 Search-ephemerides for Comet I896 VII. (Perrine) . I70 Observations of Jupiter . . . . . . . . . I70 The Orbit of X Sagittarii, a Cepheid Variable . . I70 The Leeds Astronomical Society . . . . . . . . . I70

The Solar Eclipse of June 17, 1909 . . . . . . 17 I

Recent Improvements in the Internal-combustion Engine. I. By H. E. Wimpers

Continuation Schools and National Efficiency. By J. Wilson .

Changes in Colour among Tropical Fishes. (Illus. trated.)

Mineral Output of the United States. By Prof. Henry Louis

The Institution of Mechanical Engineers

Mr. Haldane on the Promise of Aviation

mprovements in Production and Application of Guncotton and Nitroglycerine. II. By Sir

Frederic L. Nathan, R.A. . . . . . . . . 178

University and Educational Intelligence. . . I80 